\title{
Art, Architecture, and Spaces in Greek Participatory Communities
}

\author{
Tonio Hölscher
}

\section{Introduction: Democratic Visual Culture-or Visual Culture in Democracies?}

When the Athenian statesman Cleisthenes introduced to Athens his political order of isonomia, which eventually led to the Greek form of demokratia, one of his major goals must have consisted in bringing the citizens together to form an interactive citizen-body. This strategy clearly implied a new concept of political spaces and of human behavior within them. Within the territory of Attica the local settlements of the demoi (demes) were made the basic units of the citizen-body; their citizens were brought together with those of demoi from other parts of the country in one of the ten phylai (tribes), thus creating a powerful network of political communication (see Rhodes, Chapter 8).

Within the city of Athens, the three great areas of public space, the agora, the great sanctuaries, and the common burial grounds, significantly changed their character, forming a clearly structured political center. On the one hand this new "image" of the urban spaces of Athens was caused by transformations of their physical appearance, on the other hand by changes in social practice, by the use the community made of them. For if democracy essentially means participation of the citizens in political affairs, and if such participation in Greek societies essentially meant concrete interaction of the members of the community ("présence civique": Christian Meier), then democracy can be expected to have exerted a deep impact on those societies' concepts of men's communicative actions, behavior, and visual appearance in space and time. This again may be expected to have had marked consequences for those cultural practices that were most intrinsically connected with visuality: the visual arts.

Yet we should be suspicious of clear-cut answers regarding a highly complex problem. The quest for the interrelation between democracy and visual culture can go in two different directions. On the one hand one may ask whether there was-in ancient Greece

A Companion to Greek Democracy and the Roman Republic, First Edition. Edited by Dean Hammer.

(c) 2015 John Wiley \& Sons, Ltd. Published 2015 by John Wiley \& Sons, Ltd. 
or elsewhere-a specifically democratic version of visual culture, differing from that of other, non- or less democratic societies. On the other hand one can aim to understand in which way a common repertoire of visual culture was adopted in specifically democratic contexts. Are we dealing with democratic culture and art-or with culture and art in democracies? (For some decidedly historical approaches to "classical" art: Osborne 1998; Hölscher 1998b; Tanner 2006; Stewart 2008).

"Visual culture" in this context is conceived as the entire spectrum (1) of the visual forms of social practice and behavior, (2) of the visual perceptions of the world, and (3) of the creations of visual "art." In ancient Greece, these three sectors were deeply interconnected. Greek culture can be defined as a "culture of immediate acting." All issues of political and social communities were carried out through immediate interaction of their members: political decisions were taken in face-to-face assemblies, war was fought in immediate encounters, man to man, athletic games were conducted in personal competition, and social communication, for example in the symposion, was realized in intimate situations of physical presence. All this entailed wide-ranging consequences for visual culture: face-to-face means eye-to-eye. Claims to public renown and position had to be negotiated in public situations where a charismatic public appearance (along with rhetorical skill) of individual persons was of paramount importance. Physical beauty was equated with a virtuous character, and both together were elevated to an exemplary model of (manly) "best-hood." Last but not least, this social habitus deeply stamped Greek art: human bodies, actions, and interactions constituted the primary themes in the world of images, which was an essential part of the social world.

From the origin of the Greek polis-state in early archaic times, "cities" were conceived as social spaces of a highly communicative character. The agora as the center of civic life, the urban and extra-urban sanctuaries, and the necropoleis outside of the city gates constituted distinct public areas where the citizens interacted with the members of their ideal tripartite polis community: with their co-citizens (agora), their gods (sanctuaries), and their ancestors (tombs) (Hölscher 1998a).

These spaces of public interaction were stages of visual performances; therein, works of art and handicraft played their role in public display as well as in private use. Images in ancient Greece (and Rome) were not works of "art" in the modern sense, destined for primarily aesthetic perception; they were elements and factors of the social world, conveying meaning to public and private spaces and actions. There they confronted the viewers with ideal models of physical and ethical valor. The visual world of human society and the images within this world merged in reciprocal interaction.

What was the impact of democracy or a more expansive participatory politics on this visual kosmos? Or conversely: how did democracy make use of these visual tools and strategies? Generally speaking, the fifth century was an age of emphatic political identity. The Greeks as a community fenced themselves off conceptually from the surrounding cultures of "barbarians," while individual city-states within Greece developed strong patriotic ideologies. Athenian democracy above all was a highly self-assertive enterprise. Through the reforms of Cleisthenes ( $507 \mathrm{BCE}$ ) and Ephialtes (461 BCE) policy became the most important aspect of civic life, increasingly dominating other cultural sectors such as religion, athletics, and theater, as well as the "private" sphere of the oikos. The new political order was not taken as a given fact but was under continual debate, and therefore in need of 
massive self-definition and self-assertion. No other polis-state brought its political identity so much to the fore as Athens did. In this process, public buildings and images, cults and rituals were of primary importance.

\section{Urbanism: Shaping Societies}

We begin with the space of the city itself. A significant role in urban planning was played by Hippodamos of Miletus, a city designer of high ambition. He is reported to have designed the newly founded harbor city of Athens, the Peiraieus (second quarter, fifth century) and Athens' daughter-city Thurioi in south Italy (444 BCE); controversial is his activity in the foundation of the city of Rhodos (409 BCE) (Castagnoli 1971; Gehrke 1989).

Hippodamos developed his concepts on the basis of orthogonal city planning which had its origin in archaic "colonial" cities, from the Black Sea to Sicily. In contrast to such forerunners, he seems to have introduced a clearer distinction between a small number of wide main streets (plateiai) and normal narrower streets (stenōpoi), delimiting shorter blocks of houses, as attested in Piraeus and in Rhodos, as well as in better-preserved fourth-century cities like Olynthos and Priene. Thereby the crisscross communication among the citizens was intensified, which corresponds to Cleisthenes" "bringing together" the citizens of Attica. Hippodamos' theoretical importance, however, seems to have been in his role as a political thinker, conceiving of an ideal society consisting of warriors, farmers, and craftsmen. His great achievement was a rational distribution (diairesis) of functional spaces. The territory surrounding the polis was to be divided into one-third for meeting the costs of the state's sacred institutions, one-third for paying the soldiers, and another third for "private" farming. Though specific information is lacking for the city space, some analogous principles may be assumed, such as sacred, political, and residential areas, each set into functional relation to the other. Most probably these concepts were never turned into reality, but they testify to the far-reaching ambition, characteristic of this period, to shape society through rational thinking.

On the other hand, the old cities that had grown for centuries from village settlements to urban centers never changed their irregular layout. Basic structures, such as the design of streets and the localization of sanctuaries, could not easily be changed; thus, innovations were restricted to single areas within the given structure. Athens was particularly efficient in reshaping its urban appearance. This was not a democratic feature as such since most of these measures are not specifically bound to democracy, but was a result of the specific political and economic dynamism Athens developed in its democratic phase. The driving force in this process was the "state," that is, the citizens' assembly which decided on public buildings. Until the middle of the fifth century, private persons like Cimon continued the archaic tradition of distinguishing themselves by financing public buildings; normally, however, their sponsorship was integrated, as an expected contribution (leitourgia), into the democratic state's budget and building programs. The power of urban development in democratic Athens is evinced in Thucydides' famous comparison with Sparta (1.10.2): once these cities were deserted, a future visitor would get the impression from their buildings that the latter was totally insignificant whereas the former would appear twice as powerful as in fact it was. 


\section{Political Spaces: Public Installations and Buildings}

\section{Athens}

The new democratic order of Athens caused significant changes in the public spaces of the city. The configuration of civic spaces, with the agora and the Acropolis as ideal centers of the urban residential quarters, surrounded by the inland territory and the coastal zones, follows a clear structure. Although it seems doubtful, for chronological reasons, to ascribe this to a unique act of Cleisthenes, based on his exceptional capacity of geometric thinking (Levêque and Vidal-Naquet 1996), a sequence of substantial changes added up to an impressive system of democratic spaces.

The emergence of the agora of Athens and the impact of democracy in this process are issues of continuous scholarly debate. The prevailing view that an "old agora" (archaia agora), different from the later marketplace, was located in the northeast of the Acropolis was recently questioned with powerful arguments (see the discussion in Papadopoulos 2003; contra: Doronzio 2011). Most probably, the Athenian agora existed with its definite size in its definite place at least from the first half of the sixth century (Camp 1986: $35-60)$.

After Cleisthenes, political institutions became more and more predominant in the agora. Athenian democracy aimed to discuss and to decide on all matters of common interest by immediate interaction, face to face, which entailed an enormous increase of "civic presence." A large bouleuterion was built for the meetings of the 500 members of the council (boute ), as well as a circular building (tholos) for the council's fifty permanent representatives (prytaneis), where the official standard measures and weights of the state were also kept. For the increasing number of trials new law courts were installed all over the city; although they are difficult to identify, some of them are probably to be recognized in the northeastern part of the agora. These basic activities of the democratic state entailed the presence of hundreds, even thousands, of jurors, of relatives, friends, and supporters of the accused, and of all kinds of curious spectators. A group monument representing the ten eponymous heroes as exponents of the citizen-body served, with its high pedestal, as a board for public announcements for the people's assembly and for military service, addressing a wide public: a symptom of a growing city where the traditional face-to-face relations became more and more difficult. At the edges of the area various porticoes were erected as multi-functional spaces for business or personal encounters and for watching all kinds of events and rituals in the agora, protected from sun or rain: on the north side was the "painted portico" (stoa poikile $)$ containing a cycle of patriotic paintings; on the northwest side was the portico of Zeus Eleutherius (the Liberator) commemorating freedom from Persian domination; on the south side was a particularly long portico providing a series of rooms for offices and business banquets. Within the agora area a certain distribution of functions seems to have taken place: cults and jurisdiction were concentrated in the northwestern part, business on the south side, while market activities seem to have been expanded in the whole area and its periphery, especially towards the southwest and east (Rotroff 2009).

Through this development, the agora soon became so overcrowded with various mass events, like political assemblies, public trials, and religious festivals, that some of its functions had to be transferred to other places. First, dramatic competitions were installed in 
a new theater on the south slope of the Acropolis (where at the beginning of the event the tributes of the allies were publicly presented); then the people's assembly was moved to a theater-like meeting place on the Pnyx hill; finally, in the later fourth century, athletic contests moved to a new stadium in the southeast, outside the city walls. Political issues were so much at the center of democratic Athens that public spaces were more differentiated than in any other Greek city (Millett 1998).

In later periods, political installations were given great priority in times of a recovery of democracy (Knell 2000). Immediately after the catastrophic defeat in the Peloponnesian War (404 BCE) a new bouleuterion was built, the tholos of the prytaneis was restored, the state mint was installed in the agora, and above all the meeting place of the people's assembly on the Pnyx was totally rebuilt at great cost. Finally, during the revival of democratic power under the financial politician Lycurgus in the 330s a new monumental law court was begun on the agora, the Pnyx assembly site was greatly enlarged, and the theater of Dionysus was reshaped according to the actual exigencies of staging all kinds of performances and public events for large audiences. Still in this late period, such projects testify to the ongoing power of Athenian democratic institutions and practices (Hintzen-Bohlen 1997).

\section{Other cities}

Each city had its own spatial features. Metapontion in south Italy, with its wellinvestigated agora, containing a vast sixth-century circular meeting place, clearly shows that elaborate multifunctional installations for religious and political events could be conceived long before democracy. Similar facilities in Agrigento and Poseidonia, of fifth-century date, are difficult to relate to specific political systems (Mertens 2006: 315-323, 337-339). Mainland Argos, on the other hand, clearly demonstrates what democracy could achieve. Turned into a democratic state in $461 \mathrm{BCE}$, the city was quick to reshape its agora. New political needs were fulfilled by a large, columned hall for the city's council, built immediately after the democratic reform; by a large building including a court, perhaps serving for the youths' athletic training; and by a new rectangular theater for the people's assembly, some 200 meters away on the slope of the Acropolis hill. Through these buildings, the urban center was newly conceived as a constellation of differentiated spaces for all ages, for both sexes, and for the whole body of citizens as well as for the elite of the council (Marchetti and Kolokotsas 1995; Piérard and Touchais 1996: 40-54).

Yet public architecture did not so much depend on democratic constitution as on democratic self-consciousness, paired with economic power. Thasos, for example, as long as it was under Athenian dominion until the end of the Peloponnesian War, obviously made no great effort to adorn its agora or to erect buildings for its democratic institutions. Only in the fourth century $\mathrm{BCE}$ did the city give its public center a representative appearance: first with a temple of Zeus Agoraios Thasios and an altar with a statue of the famous athletic victor Theagenes, later by a two-winged stoa, perhaps the seat of the highest magistrates (archontes), a multifunctional building for the magistracies of public order, a bouleuterion for the council(?), and great porticoes delimiting the area. This sequence seems to mirror public priorities: first cults of patriotic identity, then administrative offices and installations for general comfort. The increasing impact of private 
donations that is characteristic of this period can be seen in the two-winged stoa at the agora as well as in a large hall for public meetings and banquets (Thersilocheion) further east, both with monumental inscriptions naming their rich sponsors (Grandjean and Salviat 2000).

For newly founded cities of the fourth century, the general plan, with public spaces for religious and political functions, was fixed from the beginning but only later filled out. Megalopolis, the new capital of Arcadia founded in 369 BCE after the defeat of Sparta, was designed with an impressive civic center, along a north-south axis: the center of the city was constituted by an agora including a spectrum of significant sanctuaries, as well as localities for the civic council (bouleuterion) and the magistrates (archeia), and framed by wide porticoes; further south, beyond the river Helisson, there followed installations for mass events: a large covered pillared hall (Thersileion) for the meetings of the Arcadian League, impressively towered over by a theater, the greatest in Greece, used for the citizens' assemblies (Lauter-Bufe and Lauter 2011). Likewise Messene, which at the same time was re-founded after the liberation from Sparta, got a vast agora with an adjacent theater, a temple of the city-goddess Messene, and further sanctuaries, followed by a sanctuary of Asclepius, and a kind of stadion, all aligned on the same axis (Müth 2007; Themelis 2010). Particularly revealing is the new foundation of Priene, around the middle of the fourth century BCE, where political installations were primarily laid out as functional spaces and only later shaped into representative state architecture (Rumscheid 1998; von Kienlin 2004).

\section{Political Spaces: Imagery}

\section{Political monuments}

The most conspicuous visual media of political self-assertion were monuments in the political space of the agora. Immediately after the institution of the new political order by Cleisthenes, the Athenians erected two monuments that embraced the whole spectrum of their political identity: On the Acropolis they celebrated the first victory of the newly conceived citizen army, against Chalcis and the Boeotians in $506 \mathrm{BCE}$, with what seems to have been the first Athenian state dedication to their city-goddess: a bronze four-horse chariot and the fetters of captured enemies (Raubitschek 1949: n.168). At the same time they honored the "tyrannicides" Aristogeiton and Harmodius with statues in the Athenian agora for their daring attempt on the lives of the tyrants Hippias and Hipparchus (514 BCE). This monument was in various respects a groundbreaking innovation. Whereas hitherto all monumental art had religious functions, as cult images in temples, votive offerings in sanctuaries, sepulchral images on tombs, these statues served exclusively political aims: commemoration of a great political achievement, in the political center of the city. In this sense they were not only a glorifying work of art but a political manifestation: first, they had to be decided on and pushed through, no doubt after controversial debates, by the citizens' assembly; afterwards, they served as compelling examples of civic bravery for all citizens that assembled in the agora: ideally, each Athenian citizen was to become a potential tyrant-slayer (Brunnsaker 1955; Taylor 1981; F. Hölscher 2010). Together, these monuments represented the political identity of Athens in its two main aspects: exterior military strength and interior civic freedom. 


\section{Portrait statues}

The tyrannicides, heroes credited with having slain tyrants to make way for a more participatory community, were the first images of (nearly) contemporary individuals with a primarily political significance. In the archaic period images of individual persons were erected on tombs; sometimes also votive statues in sanctuaries could be given individual names through inscriptions. Aristogeiton and Harmodius, however, were celebrated by the political community in the political center as the founding heroes of the new political order. Such public honor, though, created problems in the context of democratic egalitarianism: How much should leading persons be elevated through lasting monuments over the collective community? The tyrannicides, having been put to death, were out of political competition and therefore beyond public debate. But afterwards, as long as a strong collective spirit prevailed in Athens, no living politician was distinguished by the Athenian people through a public image on the agora. The Marathon painting, being a private commission, was a different matter; yet even in this case controversies are reported to have arisen in the people's assembly whether Miltiades or, rather, the citizens' army merited the glory of defeating the Persians. Significantly, the portrait of Pericles on the Acropolis, set up through a private initiative probably after his death, shows him without any individual features, as a typical representative of the Athenian citizen-body.

Only in the fourth century, when a majority among the citizens was increasingly ready to acknowledge an exceptional position of renowned politicians, did the erection of public honorary images become a common feature of Athenian policy. Because of the great prestige that was conferred through an honorary statue, hot political debates revolved around questions such as: What deeds or virtues justified the erection of a public image? Should this be during the honorees' lifetime or after their death? Where should such monuments be erected? And even, who was to pay, the state or the honoree? From such continual discussions there developed a more or less well-defined practice of locating public images that was to become a basic feature of civic life in Hellenistic times (Tanner 2006; Ma 2013).

The public center of Greek cities was not just a space for setting up images of persons of public renown, but these statues in the course of time added up to a political physiognomy of the city. In Athens, other portrait statues were erected in other appropriate places: athletes on the Acropolis, philosophers in the places of their activity, in particular of their "schools," poets like the great tragedians Aeschylus, Sophocles and Euripides in the theater, as representatives of the city's cultural topography (Zanker 1995).

\section{Sacred Spaces: Sanctuaries}

Greek sanctuaries were not only places of personal religious piety: religion permeated the whole sphere of social life. Sanctuaries therefore played a paramount political role in Greek polis societies.

\section{Athens}

The Athenian Acropolis, which had been formed through the archaic period by the aristocratic elite and the tyrants as a splendid city sanctuary, was totally reshaped under the 
democracy into a space of patriotic pride (Hurwit 2004). The total destruction was used for a completely new concept. In a first phase, the ruins were left visible and even, by inserting the column drums into the rebuilt north wall of the Acropolis, transformed into memorials of the Persian sacrilege. Later, in 449 BCE, the radical democrat Pericles launched a highly patriotic building program that was financed, with much critique by his interior opponents as well as by Athens' allies, from the tributes of the Delian League (Hurwit 2004). The Parthenon, often wrongly described by scholars as a non-religious treasury house, conveyed to the cult of the city-goddess an overwhelming "imperial" impact through its incomparably rich sculptural decoration and its radiant colossal cult-statue (see below). The entrance building (Propylaia) to the precinct was shaped like a theater stage with side wings where ritual processions could enter and exit with great visual effect. Beside the entrance, a most elegant Ionian temple of Athena Nike (the Victorious) towered over the steep bastion like a triumphant victory crown. Last but not least the ancient cult of Athena Polias was united with many other cults of local gods and heroes, bound to venerable places, in a multiplex temple building, the Erechtheion. The Athenian Acropolis thereby became by far the most magnificent cult center of any Greek polis, exhausting the financial means of their allies and absorbing the best workers from all over Greece. When at the Panathenaic festival the delegations of the League were forced to participate in the public ritual, they became eyewitnesses to democratic Athens' political superiority that, paradoxically, was felt by many to be a kind of tyranny.

Within the city, the gigantic project of the tyrants to erect a monumental temple to Zeus Olympius was spectacularly abandoned and demonstratively left at an early stage of its development. Instead, new cult places were founded that marked the political claims of the community, notably celebrating the glory of the Persian Wars, as well as of individual politicians. On his own initiative, Themistocles, the ambitious general of the battle of Salamis, founded a private sanctuary of Artemis with the ambitious surname Aristoboule ("Giver of the Best Advice," i.e. regarding the strategy in the battle), thereby celebrating himself as the goddess's favorite-which caused considerable criticism among his fellow-citizens (see Travlos 1971, under the specific entries). Much more successful was his rival Cimon when in 476/5 BCE he transferred the bones of Theseus, who was reported to have helped the Athenians at Marathon, from his alleged tomb at Scyros to Athens, (re-?)founding this polis hero's sanctuary as a major precinct of young men's rituals. The Theseion was decorated with two large mythological panel paintings, representing the city hero Theseus as a prototype of two major ideological claims of present policy: his help to his friend Peirithoos in the fight against the centaurs, as an exemplary demonstration of Athens' aim to support allied cities in situations of danger, and the battle against the Amazons, as a testimony to her capacity of defending herself against aggression by foreign enemies. The affinity of these paintings to those of the Stoa Poikile testifies to close interconnections between sacred and profane public architecture (Castriota 1992: $33-63)$.

The second half of the fifth century saw a particularly powerful upswing of Athenian ideological claim to autochthony, i.e. to have lived forever in the Attic lands, and of local cults emphasizing Attic identity. Just as the Acropolis was embellished by the Erechtheion, so the agora was distinguished by the new temple of Hephaistus, father of the mythical Athenian king Erechtheus, towering on the Colonus hill over the civic center (Barringer 2008: 109-143). Complementary to this, the structure and sphere of the families (oikoi) were strengthened in the second half of the fifth century through an 
increased emphasis on cults and images of Aphrodite. Laws defining Athenian citizenship on the basis of marriage between genuine Athenians seem to have affected the cult of Aphrodite in the demes, in Athens as well as through Attica. Various sanctuaries were installed or re-equipped with new images of the goddess: one on the north slope of the Acropolis, another one, with a cult statue by Pheidias, northwest of the agora. Outside of the city, the old precinct of Aphrodite Ourania was distinguished through a new cult statue, graciously leaning on a pillar, created by the sculptor Alcamenes; replicas of this image were placed in parallel sanctuaries such as at Daphne (Weber 2006).

As in the realm of policy, the recovery after the catastrophe of the Peloponnesian War caused a revival of religious installations. While the Acropolis was defined as a monument to Athens' classical glory, a vast court building, the Pompeion, was erected near the main entrance gate of the city where the great procession of the Panathenaic festival was set up. Later, towards the end of the fourth century, the agora was equipped with two highly significant temples: for Apollon Patroos, the father god of the Ionian tribe within which Athens claimed the role of a leader; and for Zeus Phratrios and Athena Phratria, gods of the family groups (phratries). Both cults emphasized the archaic social roots of the Athenian citizen-body. Thus, in the final phase of classical democracy old and new structures were integrated in a concept of political and religious restoration (Hintzen-Bohlen 1997).

At the same time, the emergence of prominent benefactors within the democratic society became particularly evident in the elaborate tripod monuments erected by sponsors of victorious choruses in dithyramb competitions: conspicuously lined up along the Tripod Street on the east slope of the Acropolis, they gave prominence to an elite of wealth within the democratic society (Goette 2007).

Democratic Athens was also prominent in marking its claim on its unusually extended territory through conspicuous sanctuaries. From ca. $450 \mathrm{BCE}$ the Acropolis project was supplemented by an ambitious program of temple building, mostly at the borders of Attica: splendid new temples were erected at Cape Sounion for Athena and Poseidon; at Brauron for Artemis; at Rhamnous for Nemesis; and at Eleusis for Demeter; while inland, probably at Pallene, a temple for Athena (and Ares?) was built (which under Augustus was transferred to the city agora). Through participation in great state rituals, processions, and sacrifices, the population of Athens, male as well as female, adults as well as children, could mark and experience their dominion over their territory (Parker 1996: 154).

Temples and cult places added up to a new concept of religious topography, conceived and reshaped in the spirit of a democratic society. As in the agora, the decisive feature of this sacred topography is that it is not only a static "image" but a semantic space to be used by the population, especially on the gods' or goddesses' public festivals: through processions and other rituals, animal sacrifices and subsequent banquets, by moving, viewing, and feasting, large parts of the Athenian citizen-body made a concrete experience of their city and territory.

\section{Other cities}

At Argos, too, the change to a democratic order around 460 BCE caused a new articulation not only of political spaces but also of religious topography, within as well as outside the city. Particularly impressive is the building activity in the famous extra-urban sanctuary of 
Hera which represented the recently established power of democratic Argos within the territory of the Argolid: a new terrace providing an impressive, tribune-like flight of steps for spectators to watch processions as they arrived and the subsequent competitions, was destined to support a new temple; the cult-image image of the goddess, created by the great sculptor Polycleitus with gold and ivory, was to equal Phidias' Athena Parthenos in Athens. In both cities, democratic power expressed itself in similar forms (Piérard and Touchais 1996).

Among the newly founded late classical cities, Megalopolis as well as Messene had its political cults concentrated on and around the agora (see above). A significant feature of religious topography in these communities of groups of different provenance was the installation of new personified city-goddesses, Megalopolis and Messene, who addressed the whole people without privileging only one part (Lauter-Bufe and Lauter 201 1; Müth 2007). At the same time Priene, which was transferred from its old to a new site, seems to have preserved its traditional separation of its religious and political areas: the central sanctuary of Athena Polias with the temple of the famous architect Pytheos was, together with the city wall, the first and most ambitious public project. Financial contribution by Alexander the Great confirms that at that time sacred buildings had the first priority for a city's identity. As in Athens, a festival called Panathenaea was celebrated. Beside this city cult a sanctuary of Demeter at the margin of the housing area was part of the original plan, offering a specific space to the female part of the population. Other cults were integrated in functional buildings, such as the Prytaneion (Hestia) and the theater (Dionysos) (Rumscheid 1998).

\section{Sacred Spaces: Imagery}

\section{Temple decoration and cult images}

Ever since archaic times the main temples of Greek poleis and their lavish treasuries in panhellenic sanctuaries had been distinguished by precious sculpted decoration, such as metopes, friezes, pediments, and acroteria. The themes of these figurative compositions, mostly mythological, celebrated exemplary feats of Greek heroes, without specific reference to the respective polis. Yet in the early fifth century the aristocratic city of Aegina chose for the pediments of its splendid extra-urban temple of Aphaia scenes of the first and second Trojan Wars in which Aeginetan heroes played a predominant role. At the same time, an analogous patriotic spirit is visible in the Athenian treasury at Delphi, later also in the temple of Hephaistus overlooking the Athenian agora, where the Athenian hero Theseus appears on public buildings, equal to the panhellenic hero Heracles. Thus, aristocratic and democratic states alike began to make use of indigenous heroes for their political self-assertion.

Most emphatically architectonic sculpture was used to arouse patriotic feelings in the Parthenon (Hurwit 2004: 106-154). Its themes develop a significant triad of ideological topics: in the pediments, the birth of the city-goddess Athena and the struggle between Athena and Poseidon for power over Attica signify divine protection; on the metopes, the fights of the gods against the giants, the Lapiths against the centaurs, the Athenians against the Amazons, and (although less directly) the Greeks against Troy are models of heroic prowess against the uproar of forces of hybris and godlessness, by implication 
referring to the recent victories of the Greeks, in particular the Athenians, over the Persians; while on the frieze the community of Athenians appears - despite all divergent interpretations - in a solemn religious procession, offering the new cloth (peplos) to the city-goddess at the festival of the Panathenaea. Divine favor, heroic virtue, and human piety add up to a comprehensive vision of a state claiming leadership all over Greece.

What the frieze presents is not the political structure of the Athenian state but the religious order of its community. Most surprisingly, however, in this order of the democratic citizen-body, great emphasis is given to the display of aristocratic traditions: four-horse chariots with warriors performing the ritual exercise of apobatai followed by a splendid cavalcade of young horsemen. Significantly, democratic Athens never developed a specific ideology of the people (démos) but ideally aimed at elevating the whole people to the rank of an aristocracy (Hurwit 2004: 133-146, 224-236).

The cult images in the temples of democratic cities were in principle stamped by the general development of the notion of gods during this period. Exceptionally, the Athena Parthenos in the Parthenon, with its colossal height of some 10 meters and its glittering surface of gold, ivory, and other precious materials, was meant to be an overwhelming demonstration of Athens' political power. Its sculptural adornment not only comprised the great myths of warlike valor, gigantomachy, and amazonomachy on the shield, and centauromachy on the edge of the sandals, but also the birth of Pandora, probably meant as a promise of gifts by the gods to humankind (Hurwit 2004: 146-154).

\section{Votive offerings}

Dedications to the gods have two sides: on the one hand they are an act of conveying gratitude and honor to the divine addressee, on the other they are a display of the dedicant's piety, and often also of his social rank and political power. Thus, monumental votive offerings could also become manifestations of a state's political order or a statesman's political ambition.

State dedications. Democratic Athens seems to have introduced a new device of state dedications to its city-goddess Athena. In archaic times, cities erected temple buildings with cult statues to their gods, whereas votive offerings, often in the form of sculpted images, were dedicated by individuals. Contrary to this, the chariot monument celebrating Athens' victory against Chalcis and Eretria in 506 BCE seems to have been the first dedication of the Athenian citizen-body. Later, towards the middle of the fifth century, the Athenians crowned the Acropolis with a colossal bronze statue, almost 10 meters high, of Athena Promachos ("Fighting for her City"), which was declared to have been built from the spoils of Marathon. Thus, the memory of the Persian defeat was towering over the sanctuary and the whole city (Hurwit 2004: 79-84). Pericles' rebuilding program of the Acropolis, starting in 449 BCE, was accompanied by statue dedications that, together with the older monuments of military victory, formed an impressive "entrance court" to the city sanctuary of democratic Athens. Thereby, the Acropolis became an almost oppressively overwhelming stage of state ceremonies, at the Panathenaic festival and on other occasions, in face of the Athenian allies and of all other Greek states.

Almost overpowering was the Athenian presence on the panhellenic stage of the sanctuary of Apollo at Delphi: a (statuary?) monument of unknown content beside the Athenian treasury house, erected immediately after Marathon; a large portico 
sheltering Athenian spoils from the expulsion of the Persians after their retreat from Greece; a monument of Athena on a palm tree after a great defeat of the Persians at the Eurymedon river (southern coast of Asia Minor) in the 460s; and a vast group of gods and Athenian heroes, surrounding Miltiades the general of Marathon, at the entrance to the sanctuary, dedicated around 460 в

Self-assertive monuments in panhellenic sanctuaries were not a specific feature of Athenian democracy: other states shared the same practice, which resulted in a competitive war of monuments, waged on the venues of great local and panhellenic sanctuaries (Hölscher 2010). In the early fifth century BCE, this competition began as a multi-voiced interplay between cities of various parts of the Greek world and of various political constitutions. Later, however, Athens became more and more the prominent player in this competitive concert of monumental dedications, occupying the most conspicuous places of the Greek world with its monuments, stressing her identity by her gods, mythical heroes and present-time politicians, and giving them an enduring presence through images in lasting material, bronze and marble.

Allies of Athens joined this practice: Argos, after reporting a common victory over Sparta together with Athens, soon after 460 вСE marked its change to democracy with a double monument of its own heroes, the "Seven against Thebes," one erected at Delphi (beside the Athenian Marathon monument), the other in its own local agora; Messenians from Naupactus dedicated a huge pillar monument, supporting Nike goddess of victory, in the sanctuary of Zeus at Olympia, again after defeating Sparta, together with Athens, in 425 BCE.

In other cases, Athenian predominance appears even more oppressive. When Samos was subdued after its revolt against Athens in 440 BCE, an over-life-size group depicting Heracles being introduced to Zeus by Athena seems to have been dedicated by the new pro-Athenian leaders, who thereby made Athens' city-goddess offensively present in the Samian sanctuary. Shortly afterwards, the neighboring city of Ephesus erected in its sanctuary of Artemis statues of wounded Amazons seeking asylum, created by Polycleitos of Argos, Pheidias of Athens, and Cresilas from Crete; thus, at the time when Athens marked its claim to the dominant position among Greek cities by the excessively ambitious building program of its Acropolis sanctuary, involving artists and artisans from all parts of Greece (see above), Ephesus emphasized the great mythical tradition of its own city cult with a monument commissioned from the most famous sculptors of the time (Hölscher 2000). Ultimately, however, the (pro-)Athenian memorials in Delphi and Olympia were overdone by even greater Spartan monuments after the final defeat at the end of the Peloponnesian War (404 BCE). Votive monuments were efficient weapons, used by various states in the political struggle for power.

Private dedications. In archaic times upper-class citizens used to emphasize their social rank by dedicating large-scale votive statues to the main city-gods. In the fifth century such private dedications seem to become rarer but even more politically ambitious. In Athens around $450 \mathrm{BCE}$, the conflict between "aristocrats" and "democrats" led to a competitive practice of erecting ambitious monuments: "aristocrats" like Callias, son of Didymus, or Pronapes presented themselves as athletic victors, while Pericles erected a group representing his father Xanthippos, a successful general in the Persian Wars, together with the poet Anacreon, anticipating his own concept of combining military strength and cultural power; after his death, Pericles himself was honored with a portrait statue at the entrance of the Acropolis, reminding visitors of the man who had initiated 
this program. While on the agora honorary statues were dependent on the community's decision, private votive statues on the Acropolis had to keep a balance between personal ambitions and critical reactions of the public (Raubitschek 1949).

\section{Atbletes' images}

Already in archaic times, athletic victors in the panhellenic games began erecting votive statues of themselves in the sanctuaries of the gods in gratitude for their success. Although they mostly came from the upper classes, athleticism was in principle an egalitarian institution within the social elite since every participant could win social renown and political power by winning an athletic contest. Within the sanctuaries certain rules developed regarding the right to and practice of setting up an image. In the political context of democratic Athens, however, athletic valor was not among the highest-ranking distinctions. It is all the more revealing that in the critical phase around $450 \mathrm{BCE}$, when Pericles was about to assert his predominant position, some exponents of aristocratic circles like Callias and Pronapes expressed their opposing claims by highly ambitious monuments celebrating their athletic successes on the Athenian Acropolis. Later, Alcibiades marked the peak of his political career by celebrating his glorious victories in the four-horse chariot race at Olympia, Delphi, and Nemea through highly provocative paintings, arousing fury among the older and enthusiasm among the younger generation. Thus, in the context of Athenian policy the widespread traditional practice of athletic images was adopted as a strategy of aristocratic opposition, and to some degree as a compensation for the restricted honor of a public portrait statue (Rausa 1994).

\section{Mythological and Historical Topography}

Greek cities were stamped by traces of their mythical origins, which were held to be their "real" prehistory, and their subsequent historical past. Such traces were powerful symbols of political identity. The locations of mythical events were rarely remembered from primeval times but were mostly invented and attributed in later epochs. Dating such traditions is often difficult; some of them must go back to archaic times. Yet fifth-century Athens seems to have been particularly active in creating and emphasizing its mythical past. A conspicuous example is the Erechtheion on the Acropolis which includes traces of the combat between Athena and Poseidon over the possession of Attica in the north porch, and the Maiden porch over the tomb of King Cecrops. Aeschylus locates the camp of the Amazons, assaulting the Acropolis, on the Areopagus hill, and in the fourth century a whole topography of the glorious battle of the mythical Athenians under Theseus against the Amazons was "reconstructed" within the urban space of Athens.

At the same time, the topography of the Persian Wars was commemorated with particular emphasis: within the city was the area of the Persian camp, the place of assault on the Acropolis, while in the countryside of Attica there was the battlefield of Marathon, the place where Xerxes had observed the battle of Salamis, the shore where the Persian corpses were stranded, and so forth. Athens and Attica were transformed into a landscape of memories of their mythical and historical past (Hölscher 1998a). 


\section{Necropoleis}

A particular aspect of classical Greek society appears in the space of cemeteries. Sepulchral art was a public manifestation of family structures and as such was in manifold ways linked to the sphere of politics. Democracy particularly affected burial customs. In Athens, the series of splendid aristocratic grave monuments of archaic times comes to an end around and after $500 \mathrm{BCE}$ as a result either of a law, or of general social pressure, in an egalitarian spirit, against aristocratic expenditure (Morris 1992/3).

When after 440 BCE ambitious grave monuments re-emerge in Athens, they become the most significant form of social self-representation until the late fourth century, when Demetrius of Phaleron enacted a law that brought them to an abrupt end (Bergemann 1997). Typically, grave terraces, crowned by relief stelai and other figurative signs, contain burials of small or middle-sized families, mostly over two to four generations; no clans, no long genealogies. The stelai, accompanied by inscribed epigraphs, strongly emphasize the values of the family. The deceased, with their relatives and servants, appear in various combinations, in highly homogeneous civic attire and attitudes. The social focus is on the oikos as the nucleus of the polis. Its members, living and dead, are united in lifelike constellations; nevertheless, death is always present, either in explicit emotional gestures or through implicit knowledge of the stele's function. The threat to the survival of the oikos is conceived not only as a personal but also as a social concern.

Inscriptions show that the social range of this sort of self-assertion was wide, from the richest families to the middle classes, to foreign inhabitants (metoikoi) and even a few slaves. Yet, although the size and quality of the monuments indicate financial expenditure, they do not represent a clear social hierarchy. Obviously, the society's civic coherence and common values were regarded as more important than social distinction-at least in the realm of public sepulchral representation.

Perhaps the most powerful factor-product and producer-of the political identity of democratic Athens was the introduction, around $500 \mathrm{BCE}$, of the state burial for all victims of war (Loraux 1986; Arrington 2010). The democratic order required military service from all citizens; therefore, at the same time that sumptuous private burials became controversial the state provided collective compensation for the families that had lost one of their members in the service of the community. The site of the state burials, outside the Dipylon gate, was not a closed cemetery but an area where these graves were mixed with private tombs and other installations; nevertheless they were close enough to each other to be subsumed under the unifying term démosion sèma. They were supplied with lists of the victims, enumerated in columns of the ten phylai, and often adorned with reliefs representing scenes of fighting. The funerary celebrations, in the presence of the whole citizen-body, were highly charged with patriotic ideology and collective emotions. Public orations evoked the glory of the forefathers from the mythical origins of the city to the recent past, setting the achievements of the fallen co-citizens in this tradition. Emphasis is laid on struggle and death, emphasizing the value of self-sacrifice for the city. For future times these public graves added up to a conceptual facade of the city, outside of its main entrance gate.

The necropoleis of democratic Athens and its territory were the most extended burial areas with the most artistically accomplished grave monuments to be found in Greece. Since they were not fenced off cemeteries they were a part of ordinary life: the relatives 
of the deceased used to visit the tombs for regular cult and care activities, while travelers approaching the city could get a visual idea of the power of family traditions within this polis. Last but not least the state graves were one of the main places where, almost every year, the whole community of citizens came together for the public burial ceremonies, affirming and strengthening their political identity.

\section{The Private Sphere}

\section{Houses}

Private housing (see in general Nevett 1999) had developed during the archaic period in relatively small one-family units; in the old irregular cities this size was determined by social tradition, while in the newly founded "colony" cities it was in addition determined by the equal size of plots within the fixed grid system of orthogonal streets. As a general rule this was continued through the fifth century BCE, not least in the shorter housing blocks of the "Hippodamian" cities of Peiraeus, Thurioi, Olynthus, and Priene. However, the idea that Hippodamos also designed a "model house," to be adopted in an identical form in democratic states (Hoepfner and Schwandner 1994), seems to be a modernistic concept of egalitarian utopia: houses in classical cities are to some degree similar but never identical. Their similarity results on the one hand from the equal size of the plots, and on the other from a certain homogeneity in the functions that had to be fulfilled by specific types of rooms and spaces: a courtyard and a covered portico for outdoors activities in different climates, a main living room comprising a hearth and sometimes a bath tub, a secondary room, perhaps for women, and above all a dining room for the men's banquets (andrōn). If such rooms of a reasonable size were to be installed in a reasonable way - with the courtyard immediately after the entrance, the living rooms with the portico in the back part, the andron somewhat separated from the women's room - a certain similarity must have resulted without compelling prescripts. On the other hand, the well-explored houses at Olynthus demonstrate that considerable diversity could be reached through individual solutions, even within the frame of a rigorous frame of equal lots. Greek equality meant that everybody had an equal chance to become unequal.

From the late fifth century onward, social differences became more and more marked (Walter-Karydi 1998). Rich families no longer felt bound by the severe rules of an egalitarian lifestyle and invested more and more in their private housing. In Athens, Alcibiades was a protagonist of this tendency while in other places sumptuous residences become more and more frequent during the fourth century. At Eretria, the Maison aux Mosaiques is divided into two areas of different social accessibility, one representative part around a peristyle court, with three banqueting rooms for groups of varying size (with three, five, and nine couches), another part with private rooms and a less impressive court. Lavish mosaic floors, probably wall paintings, and costly furniture added to some degree of luxury. Demosthenes (Olynth. 25) reproached his wealthy co-citizens for spending their wealth more and more on private residences rather than public building. Although the often complained of decline of the public realm in late classical times is rather a modern myth than an ancient reality, a certain upswing of the private in comparison with the public sphere is undeniable. 


\section{Vase painting}

Tens of thousands of painted vases are definitely the most significant testimony to social imagery and collective mentality of archaic and classical Greece. Though in great part exported to places outside of Athens, their themes mostly correspond to what Athenian producers supposed to be the common interests of their local and foreign customers. Destined for use in highly communicative social situations, such as the symposion, weddings, and burials, vases attest to a wide range of collective "visual discourses" (Neer 2002).

Representations from social life convey highly stylized concepts of normative civic behavior and its changes from one generation to the other. Significantly, the first decades after Cleisthenes are strongly stamped by a continuation of the archaic aristocratic repertoire, in particular the joys of symposia, the beauty of athletics, and the pleasure of hetero- and homoerotic relationships. Only after the Persian Wars do the scenes of aristocratic splendor become fewer and less extrovert, and themes of reflection on social roles and norms become predominant. Fights between Greeks and Persians are depicted according to antithetical concepts of normative Hellenicity and "barbarian" otherness. Moreover, the sphere of the oikos is more and more brought to the fore. Greek warriors are shown departing from their relatives, emphasizing the social importance of the family and the risks of the increasingly expanding warfare. From the middle of the fifth century, the world of women, in a relaxed atmosphere of conversation and music, comes more and more to the fore. Ultimately, in the last decades of the fifth, as well as during the fourth, century, the private sphere of love and pleasure becomes the dominant theme on Attic vases.

The experience of the human world is in multiple forms reflected in the sphere of myths and the gods. At the very beginning of the Cleisthenic era the Athenian hero Theseus was emphatically changed into a protagonist of the democratic state. Probably on the basis of an epic poem, Theseus was equipped with a biography of heroic deeds that elevated him, as a polis hero, to the level of the panhellenic hero Heracles (von den Hoff 2010). The Persian Wars then conveyed new actuality to the old myths of the fights of the gods against the giants, the Lapiths against the centaurs, and the Athenians against the Amazons. These mythical adversaries incorporated various aspects of conceptual otherness that were felt to be in opposition to, and menacing, the Greek order of life. On the other hand, the Greek gods and heroes were elevated to ideal representatives of male prowess and dignity. Particularly efficient was the self-assertion of Athenian identity which increasingly was emphasized through myths and heroes of Attic origin. The kings Codrus and Erechtheus, sprung from Attic soil, represented the exclusive Athenian ideology of "autochthony," of having lived in Attica from time immemorial (Shapiro 1998).

The powerful upswing of the individual sphere in the last decades of the fifth and throughout the fourth centuries $\mathrm{BCE}$ has its mythical counterpart in a wave of themes around the gods Aphrodite and Dionysus. Again, the female sphere comes to the fore. Aphrodite is often set in an idyllic garden landscape, surrounded by personifications of social and psychological ideals, such as Eudaimonia and Eutychia (Happiness), Himeros and Pothos (Longing), Eukleia (Good Renown) and Eukosmia (Good Order). At the same time the sphere of male desires is embodied by young satyrs enjoying the pleasures of Dionysus. The hard and long Peloponnesian War may have intensified these tendencies, yet the general shift from the social norms of the community to the ideals of individual 
bliss started before and was to endure for centuries after this event. It was a change of paramount importance in Greek history (Shapiro 1993; Borg 2002).

\section{Art Forms, Political Ideals, and Social Values}

A general phenomenon to which architecture and art contribute in democratic cities and societies is the politicization of public life. Buildings for political functions not only give space to the activities of political institutions but also, together with political monuments, convey to these spaces a new meaning. In Athens, the agora becomes a primarily political center, the Acropolis becomes a venue of political identity, the state "cemetery" becomes an area of patriotic emotions. In these spaces, the citizens constitute themselves in a new way as a political community: in the agora in interaction with each other, on the Acropolis with the city-goddess, in the burial areas with their ancestors.

For this purpose, "history" was of paramount importance. The discovery of "history" in the fifth century BCE was not a discovery of the past but of the present. For centuries the Greeks had lived with the great pre-history of their mythical origins, as a foundation of their political, social, and cultural order of life. Through honorary statues for the Athenian tyrannicides and others, political votive offerings and "historical" monuments celebrating the victories over the Persians, tragedies like Phrynichos' Conquest of Miletus and Aeschylus' Persians, public orations at state burials, and ultimately the History of the Persian Wars by Herodotus, the present time and its immediate pre-history were explicitly elevated to public significance, equal to the myths of the heroes of former times.

The politicization of public life was based on new and powerful concepts of identity: one's own state versus other states, Greeks versus barbarians, in particular those of the east. A strong political antithesis was created between Hellenicity and Asianity which served to define, fence off, and strengthen all that was considered to belong to the ideal identity of Greece in opposition to the culture of the Asiatic enemy (for various approaches see Castriota 1992; Miller 1997; Miller and Hölscher 2013). Stock elements in this self-image were a basic equality between citizens of a polis, ethical self-control, and modesty of lifestyle. In particular, the portrait of Pericles, the most powerful statesman of classical Athens, keeps within this normative frame. Only in late classical times, beginning with the late fifth century, dominant individuals and social distinction through wealth, together with a lavish lifestyle of an "oriental” type, are acknowledged within democratic societies.

At the basis of all this lies a new collective self-confidence of human beings. As the poet-philosopher Xenophanes put it (fr. 16): "Not from the beginning did the gods reveal all things to mortals, but men by searching found the better in the course of time." In this sense, Cleisthenes did not so much modify the old political norms as create a totally new order in which all members of the community had to take decisions on all essential issues of the state and even of the political order as such. It was a widespread optimism of being able to shape the human world and social life-with the gods' favor, but through men's own efforts.

The medic-philosopher Alcmaeon of Croton (fr. 4) developed a concept of health that primarily regards the human body but has implications for the political order of the state: health is the balance of powers, wet and dry, cold and hot, bitter and sweet, whereas illness is the predominance of one of these elements. In this context, "balance" and 
"predominance" are defined by political notions: isonomia, the key term of Cleisthenes' political order, and monarchia, as its negative counter-concept. As a medic, Alcmaeon must have considered health-and by implication political isonomia - to be feasible through theoretical insight, competent knowledge, and skillful practice. In the same sense, the sculptor Polycleitos of Argos conceived one generation later a canon of the human body that was radically based on the balance of antithetical forces. In his view, art was able to create a perfect human body, as Hippodamus of Miletus conceived his ideal state and the order of the city as a balance and reciprocal interaction between warriors, farmers, and craftsmen. Thus there were marked analogies between works of art and concepts of the state and society: analogies that in part resulted implicitly from general forms of thinking in terms of opposition and balance, and that in part were explicitly conceptualized.

\section{Conclusion}

The quest for the role of art in historical contexts should not lead to one-directional answers regarding the interrelation between art and the "historical" world of policy and society: while art to some degree results from historical circumstances because it has its place therein, art also affects and changes the world it is destined for.

Recent approaches have aimed to establish close connections between Athenian democracy and the general style of "classical" art (Tanner 2006; Neer 2010). Such attempts are most fruitful and challenging in integrating the forms of style within a specific political order. On the other hand, however, there remains the fact that this style, wherever it originated, immediately spread through the entire Greek world and was adopted in democratic as well as aristocratic and monarchic states. Therefore, one must consider also other social and cultural factors relevant to this change in the arts.

There is no "democratic architecture and art," but there is massive use of architecture and art by and for democracy. The Athenian democracy was imperialistic and voracious in many respects, not least in the field of art: within the realm of the Delian League, the allies were so heavily burdened with tributes that the number of public and private art commissions fell drastically, while Athens with its gigantic project of adorning its cityscape absorbed almost all capable artists from all parts of Greece. Yet from this it does not follow that this was essentially "democratic art": indeed, some specific phenomena, such as public portrait statues and the state cemetery, were developed in democratic Athens; moreover, the conflict between the claims of leading politicians to power and the constraints of the egalitarian community appears particularly sharp in Athenian public monuments. But most types and phenomena of public architecture and art were not restricted to this specific political order. What remains is that democratic Athens was the driving force in all tendencies towards the politicization of social life, the elevation of the present time to the rank of myth, the construction of patriotic and Hellenic identity, and the ideological promotion (and factual abandonment!) of typically "Greek" social and cultural values.

What is most important in this development is the enormous intensification of public life that occurred in the civic spaces of democratic Athens. People's assemblies, with a quorum of 6,000 , meeting up to forty times a year, regular sessions of the council of 500 members, law courts with thousands of jurors every day, countless religious festivals 
celebrated in sanctuaries all over the city and beyond, athletic games and theater performances, public and private burials with great numbers of participants: all this added up to an unprecedented "civic presence" and encounters of inhabitants not only of the capital but also of the countryside. In this situation, public monuments, exalting the great feats of patriotic myth and history, prompted vivid discourses on matters of policy and patriotic identity. It was the combination of highly ambitious political and religious architecture with an intense concentration of civic energies in the realm of policy that made democratic Athens by far the most dynamic power in classical Greece.

In this respect classical Athens opened the way for a multiform practice of visual culture, installing communitarian spaces and erecting public monuments, in later states of democratic or republican constitution. The Roman Republic, not from its beginning but in its expansive phase from a polis state to a great territorial power in the fourth and third centuries $\mathrm{BCE}$, adopted great part of these elements: transforming the Forum into a space of political agency, creating a religious topography of temples for divinities of political ideology and identity, and installing a practice of reciprocal claims and acknowledgment between the institutions of the community and its leading individuals in the visual forms of public monuments and rituals. This must also have affected public life, but in contrast to Athens the emphasis in these changes was laid on increasing public dignity and political magnificence, adequate to Rome's increasing ambition to rise among the great powers of the Mediterranean; accordingly, the Forum was reserved for political and elevated economic activities, while state cults were installed and performed for gods and goddesses of political concepts like Salus and Victoria, Virtus, Honos, and Pietas. Thus, in Rome the politicization of public spaces and monuments was developed into a powerful instrument of political contest, but the beginnings of this concept are to be traced back to Athens and other participatory communities in fifth-century Greece.

\section{REFERENCES}

Arrington, N. 2010. "Topographic Semantics: The Location of the Athenian Public Cemetery and its Significance for the Nascent Democracy." Hesperia 79: 499-539.

Barringer, J.M. 2008. Art, Myth, and Ritual in Classical Greece. Cambridge.

Bergemann, J. 1997. Demos und Thanatos. Untersuchungen zum Wertsystem der Polis im Spiegel der attischen Grabreliefs des 4. Jahrhunderts v.Chr. Munich.

Boedeker, D. and K. Raaflaub, eds. 1998. Democracy, Empire, and the Arts in Fifth-Century Athens. Cambridge, MA.

Boersma, J.S. 1970. Athenian Building Policy from 561/60 to 405/4 B.C. Groningen.

Bommelaer, J.-F. 1991. Guide de Delphes: le site. Paris.

Borg, B.E. 2002. Der Logos des Mythos. Allegorien und Personifikationen in der frühen griechischen Kunst. Munich.

Brunnsaker, St. 1955. The Tyrant-Slayers of Kritios and Nesiotes. Lund.

Camp, J.M. 1986. The Athenian Agora. London.

Castagnoli, F. 1971. Orthogonal Town-Planning in Classical Antiquity. Cambridge, MA.

Castriota, D. 1992. Myth, Ethos, and Actuality: Official Art in 5th Century B.C. Athens. Madison.

Doronzio, A. 2011. "L'Archaia Agora di Apollodoro e Melanzio." Quaderni Ticinesi. Numismatica e antichità classiche 40: 15-84.

Gehrke, H.-J. 1989. "Bemerkungen zu Hippodamos von Milet.” In Schuller, Hoepfner, and Schwandner 1989: 58-63. 
Goette, H.-R. 2007. "Choregic Monuments and the Athenian Democracy." In P. Wilson, ed., Greek Theatre and Festivals: Documentary Studies. Oxford, 122-149.

Grandjean, Y. and Salviat, F. 2000. Guide de Thasos. 2nd edn. Paris.

Gruen, E.S., ed. 2011. Cultural Identity in the Ancient Mediterranean. Los Angeles.

Hintzen-Bohlen, B. 1997. Die Kulturpolitik des Euboulos und des Lykurg. Berlin.

Hoepfner, W. and E.-L. Schwandner. 1994. Haus und Stadt im klassischen Griechenland: Wohnen in der antiken Stadt $\mathrm{I}$. Munich.

Hölscher, F. 2010. "Die Tyrannenmörder-Ein Denkmal der Demokratie." In E. SteinHölkeskamp and K.-J. Hölkeskamp, eds., Die griechische Welt. Erinnerungsorte der Antike. München, 244-258.

Hölscher, T. 1974. "Die Nike der Messenier und Naupaktier in Olympia: Kunst und Geschichte im späten 5.Jahrhundert v.Chr." JDI 89: 70-111.

Hölscher, T. 1998a. Öffentliche Räume in frühen griechischen Städten. 2nd edn. Heidelberg.

Hölscher, T. 1998b. "Images and Political Identity: The Case of Athens." In Boedeker and Raaflaub 1998: 153-183.

Hölscher, T. 2000. "Die Amazonen von Ephesos: Ein Monument der Selbstbehauptung." In Agathos Daimon: Mythes et cultes. BCEH suppl. 38: 205-217.

Hölscher, T. and M. Miller. forthcoming. "Wealth, Luxury and Identity: East and West." In T. Hölscher, B. Parmann, K. Trampedach, and N. Zenzen, eds., The Antithesis East-West before and after Alexander the Great. Frankfurt.

Hurwit, J.M. 1999. The Athenian Acropolis. Cambridge.

Hurwit, J.M. 2004. The Acropolis in the Age of Pericles. Cambridge.

Knell, H. 2000. Athen im 4. Jahrhundert. Darmstadt.

Lauter-Bufe, H. and H. Lauter. 2011. Die politischen Bauten von Megalopolis. Darmstadt.

Levêque, P. and P. Vidal-Naquet. 1996. Cleisthenes the Athenian. Atlantic Highlands.

Loraux, N. 1986. The Invention of Athens: The Funeral Oration in the Classical City. Trans. A. Sheridan. Cambridge.

Ma, J. 2013. Statues and Cities. Honorific Portraits and Civic Identity in the Hellenistic World. Oxford.

Marchetti, P. and K. Kolokotsas. 1995. Le nymphée de l'agora d'Argos. Études Péloponnésiennes 11. Paris.

Mertens, D. 2006, Städte und Bauten der Westgriechen. Munich.

Miller, M. 1997. Athens and Persia in the 5th Century B.C. Cambridge.

Miller, M. and Hölscher, T. 2013. "Wealth and Social Identity: East and West: Between Cultural Anthropology and Political Ideology." In N. Zenzen, T. Hölscher und K. Trampedach, eds., Aneignung und Abgrenzung. Wechselnde Perspektiven auf die Antithese von, Ost' und, West' in der griechischen Antike. Heidelberg.

Millett, P. 1998. "Encounters in the Agora." In P. Cartledge, P. Millett, and S. von Reden, eds., Kosmos: Essays in Order, Conflict and Community in Classical Athens. Cambridge, 203-228.

Morris, I. 1992/3. "Law, Culture, and Funerary Art in Athens." Hephaistos 11-12: 35-50.

Müth, S. 2007. Eigene Wege: Topographie und Stadtplan von Messene in spätklassischhellenistischer Zeit. Rahden and Westfalen.

Neer, R. 2002. Style and Politics in Athenian Vase-Painting. Cambridge.

Neer, R. 2010. The Emergence of the Classical Style in Greek Sculpture. Chicago.

Nevett, L. 1999. House and Society in the Ancient Greek World. Cambridge.

Osborne, R. 1998: Archaic and Classical Greek Art. Oxford.

Papadopoulos, J. 2003. Ceramicus Redivinus. Hesperia suppl. 31. Athens.

Parker, R. 1996. Athenian Religion. Oxford.

Piérart, M. and G. Touchais. 1996. Argos: Une ville grecque de 6000 ans. Paris.

Pollitt, J.J. 1972. Art and Experience in Classical Greece. Cambridge.

Raubitschek, A.E. 1949. Dedications from the Athenian Acropolis. Cambridge, MA. 
Rausa, F. 1994. L'immagine del vincitore. Rome.

Rotroff, S. 2009. "Commerce and Crafts around the Athenian Agora." In J.M. Camp and C.A. Mauzy, eds., The Athenian Agora: New Perspectives on an Ancient Site. Mainz, 39-46.

Rumscheid, F. 1998. Priene: Guide to the "Pompeii of Asia Minor." Istanbul.

Schuller, W., W. Hoepfner, and E.-L. Schwandner. 1989. Demokratie und Architektur. Munich.

Shapiro, H.A. 1993. Personifications in Greek Art, 600-400 B.C. Zurich.

Shapiro, H.A. 1998. "Autochthony and the Visual Arts in Fifth Century Athens." In Boedeker and Raaflaub 1998: 127-151.

Stewart, A. 1990. Greek Sculpture: An Exploration. New Haven.

Stewart, A. 2008. Classical Greece and the Birth of Western Art. Cambridge.

Tanner, J. 2006. The Invention of Art History in Ancient Greece. Cambridge.

Taylor, M.W. 1981. Tyrant Slayers: The Heroic Image in 5th Century B.C. Athens. New York.

Themelis, P. 2010. Archaia Messene. Athenai.

Thompson, H.A. and R.E. Wycherley. 1972. The Agora of Athens. The Athenian Agora 14. Princeton.

Travlos, J. 1971. Pictorial Dictionary of Ancient Athens. London.

Von den Hoff, R. 2010. "Theseus-Stadtgründer und Kulturheros.” In E. Stein-Hölkeskamp and

K.-J. Hölkeskamp, eds., Die griechische Welt: Erinnerungsorte der Antike. Munich, 300-316.

Von Kienlin, A. 2004. "Das Stadtzentrum von Priene als Monument bürgerlicher Selbstdarstel-

lung." In E.-L. Schwandner and K. Rheidt, eds., Macht der Architektur-Architektur der Macht. Mainz, 114-120.

Walter-Karydi, E. 1998. The Greek House: The Rise of Noble Houses in Late Classical Times. Athens. Weber, M. 2006. "Die Kultbilder der Aphrodite Urania in der 2. Hälfte des 5. Jh. V.Chr. und das Bürgerrechtsgesetz von 450/51 v. Chr." MDAIAthen 121: 165-221.

Zanker, P. 1995. Die Maske des Sokrates. Munich.

\section{FURTHER READING}

For a wider understanding of the issues dealt with in this chapter, international bibliography, including also French, German and Italian, has to be consulted. Among works in English a recent powerful account on classical Greece and the birth of Western art is Stewart 2008. Still worth reading is Pollitt 1972. In addition see the collection of essays in Boedeker and Raaflaub 1998 on a wide range of cultural topics in classical Athens. For good surveys of the political spaces of Athens see Thompson and Wycherley 1972 and, shorter, Camp 1986, on the agora, and Hurwit 1999, on the Acropolis. For new approaches on art and democracy see Neer 2002, 2010 and Tanner 2006. Important approaches of the French school of historical sociology, available in English translation, are Levêque and Vidal-Naquet 1996 on urbanism, and Loraux 1986 on ideologies of identity. 